\title{
Pendampingan Konseling Behavioral dalam upaya Memberikan Bantuan bagi Korban Kekerasan dalam Rumah Tangga
}

\author{
Azmatul Khairiah Sari ${ }^{1}$

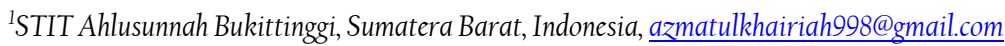

2021 by the authors. Submitted for possible open access publication under the terms and conditions of the Creative Commons Attribution-ShareAlike 4.0 International License-(CC-BY-SA) (https://creativecommons.org/licenses/by-sa/4.0/)

do) DOI: $h$ ttp://dx.doi.org/10.30983/dedikasia.vli2.4823

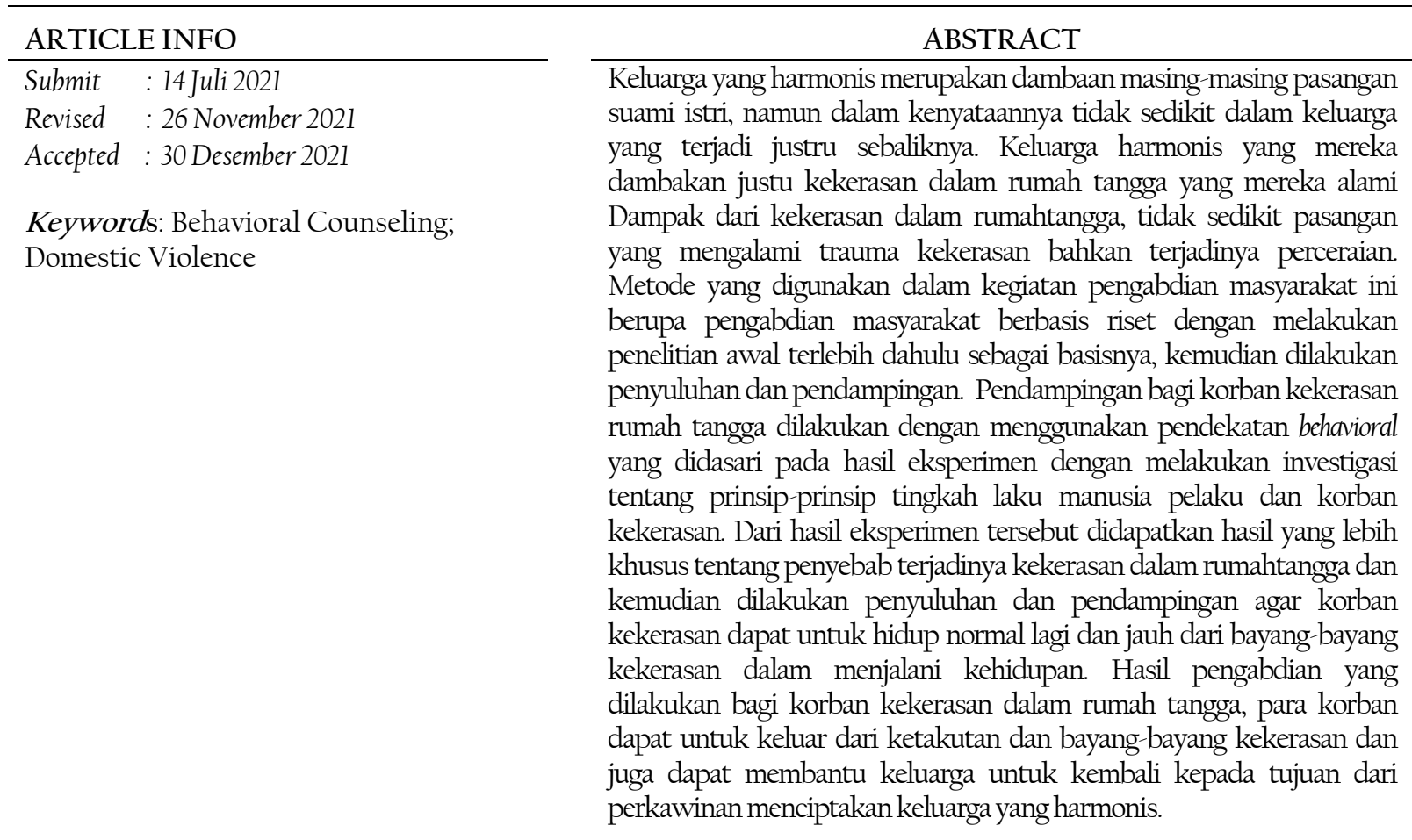

International License-(CC-BY-SA)

This is an open access article under the CC-BY-SA license

(https://creativecommons.org/licenses/by-sa/4.0/)

do: $\mathrm{p}: / /$ dx.doi.org/10.30983/dedikasia.vli2.4823

\section{Introduction}

Manusia adalah makhluk ciptaan Allah yang memiliki rasa cinta dan rasa ingin dicintai oleh lawan jenisnya. Salah satu realisasi dan wujud dari rasa cinta dan dicintai yang diridhai Allah tersebut adalah pernikahan. Pernikahan akan menjadikan seseorang bisa mewujudkan rasa tersebut dalam membangun rumah tangga yang sakinah mawaddah warahmah. Sebagai seorang muslim dan muslimah, ketika ia berbuat sesuatu dalam pernikahannya akan bernilai suatu ibadah. Tidak hanya itu, didalam rumah tangga juga terdapat anak-anak sebagai bukti kasih sayang individu yang terikat dalam pernikahan tersebut. 
Anak-anak juga butuh akan kasih sayang dan cinta dari kedua orangtuanya. Kasih sayang dan cinta dari orangtua akan menyebabkan anak memiliki kesehatan mental yang bagus. Muara dari kesehatan mental yang bagus adalah interaksi sosial yang terjadi antara anak tersebut dengan orang lain di sekitarnya akan hangat pula. Dalam rumah tangga yang penuh kasih sayang dan cinta akan menghasilkan anggota keluarga yang memiliki perilaku yang menyenangkan.

Tidak jarang sebelum pernikahan, masing-masing individu perlu mendapatkan pendidikan pra nikah supaya mereka bisa mewujudkan keluarga yang harmonis tersebut. Keluarga yang harmonis akan mengurangi angka perceraian pada pasangan suami isteri dan perlu adanya banyak informasi, pengetahuan dan pemahaman yang mendalam mengenai membangun keluarga yang sakinah, mawaddah warahmah Dewasa ini banyak pasangan suami istri yang terkejut dengan kehidupan setelah pernikahan karena banyak yang mengatakan tidak sama dengan masa ketika dulu sebelum menikah atau berpacaran. Apabila pasangan suami istri sebelumnya sudah mendapat cukup info mengenai pernikahan maka ia tidak akan terkejut dan merasa berbeda dengan kehidupan setelah pernikahan. Kehidupan setelah pernikahan yang bahagia tentu diawali dengan pengetahuan yang benar dan cukup baik tentang pernikahan.

Namun tidak semua rumah tangga yang dibina oleh suami istri diliputi oleh kasih sayang dan cinta tersebut. Banyak faktor yang menyebabkan rumah tangga tersebut malah diliputi dengan suasana kebencian dan ketakutan. Rumah tangga yang harusnya menjadi tempat mengadu, berkeluh kesah dan tempat bercanda bersama anggota keluarga yang lainnya malah menjadi tempat yang paling ditakuti. Tidak jarang kita mendapati anak-anak berkata dia lebih senang berkumpul dengan temannya dibandingkan bersama orangtua mereka. Tidak jarang kita mendapati suami yang merasa lebih nyaman bersama teman kantornya dibandingkan bertemu istri dan anaknya. Ini menjadi pertanda rumah tangga tersebut diliputi suasana kebencian dan ketidakharmonisan.

Salah satu faktor yang dapat membuat rumah tangga menjadi kacau adalah terjadinya kekerasan dalam rumah tangga. Kekerasan berarti seseorang menggunakan kekuatannya untuk menekan orang lain yang tidak berdaya. Dari pernyataan UU ini dinyatakan bahwa kekerasan dalam rumah tangga biasanya terjadi pada perempuan dan anak-anak. Hal ini tentu akan menyebabkan trauma pada perempuan dan anak-anak. Dan yang lebih parah lagi adalah adanya rasa trauma dari psikologis. Hal ini akan mempengaruhi tingkah laku seorang perempuan kepada anak dan keluarganya. Dan seorang anak akan terganggu dalam belajar karena adanya trauma di keluarganya.

Banyak dampak yang akan ditimbulkan dari kekerasan yang terjadi pada sebuah keluarga. anggota keluarga secara tidak langsung akan mendapati dampak dari kekerasan dalam rumah tangga. Dampak yang bisa dirasakan dari kekerasan dalam rumah tangga seperti rasa takut, cemas, letih, kelainan, stress post traumatic, serta gangguan makan dan tidur yang merupakan reaksi panjang dari tindak kekerasan (Ramadhani, dkk, 2015). Rasa takut yang berlebihan merupakan dampak yang 
dapat timbul dari kekerasan dalam rumah tangga. Takut untuk bersosialisasi, cemas untuk berinteraksi, letih karena memikirkan masalah di keluarga, dan bahkan bisa terganggu dalam makan dan tidur. Makan dan tidur anggota keluarga tidak akan akan menyenangkan apabila masalah dalam keluarga masih terjadi.

Untuk kasus kekerasan dalam rumah tangga harus diberikan sebuah sebuah pendidikan dan penanganan psikologis yang tepat untuk anak yang sudah terimbas dari kekerasan dalam rumah tangga. Selain itu anak adalah individu yang pada awal perkembangannya harus menguasai tugas perkembangan dengan baik. Namun apabila ia menjadi korban kekerasan dalam rumah tangga akan menyebabkan ia kesulitan dalam mengembangkan dirinya. Perempuan dan anak merupakan korban dari kekerasan dalam rumah tangga yang harus dilindungi dan diberikan sebuah pendidikan dan bantuan pengembangan psikologis.

Kekerasan dalam rumah tangga selalu mengalami peningkatan yang cukup signifikan setiap tahunnya. Dikutip dari komnasperempuan.go.id bahwa untuk kekerasan di ranah rumah tangga/relasi personal, selalu sama seperti tahun-tahun sebelumnya kekerasan terhadap istri (KTI) menempati peringkat pertama 6.555 kasus (59\%), disusul kekerasan terhadap anak perempuan sebanyak 2.341 kasus $(21 \%)$.

Dari data di atas terlihat bahwa kekerasan dalam rumah tangga memiliki angka yang tinggi. Dan semakin bertambah setiap tahunnya. Faktor pemicu terjadinya kekerasan dalam rumah tangga bisa beragam. Namun point pentingnya adalah korban dari kekerasan dalam rumah tangga. Yaitu perempuan dan anak-anak. Dampak fisik dan psikis sangat dirasakan oleh anak dan perempuan. Hal ini menjadi awal penyebab sebuah keluarga yang tidak harmonis dan tanpa adanya kehangatan. Keluarga tanpa kasih sayang dan cinta akan membuat anggota keluarga merasa bahwa keluarga adalah tempat yang tidak menyenangkan olehnya.

Adanya ketidakmampuan dari perempuan dan anak dalam melawan tindakan kekerasan yang dilakukan oleh suami atau ayahnya menjadikan isu gender kembali dipermasalahkan. Sementara, dalam Islam memberikan penghormatan kepada seorang perempuan. Islam menganggap bahwa tidak ada perbedaan antara laki-laki dan perempuan. Perempuan juga memiliki peran dalam membuat ekonomi sebuah keluarga berkembang dengan baik. Perempuan juga diberikan sebuah kelonggaran untuk memiliki usaha sendiri asalkan halal dan baik. Usaha tersebut tidak mengganggu keharmonisan sebuah keluarga. dengan begitu seorang perempuan terkadang memiliki peran ganda, sebagai ibu yang mengatur sebuah keluarga dan peran sebagai pembantu dalam mengembangkan ekonomi sebuah keluarga.

Berkaitan dengan kekerasan terhadap perempuan dalam rumah tangga, dapat dilihat berdasarkan latar belakang historis dan dikategorikan dalam tiga tipe, salah satunya adalah 
kekerasan lokal atau tradisonal. Kekerasan lokal atau tradisonal dianggap sebagai potensi yang dimiliki komunitas atau suku bangsa manapun. Kekerasan Dalam Rumah Tangga (KDRT) menjadi isu penting dalam beberapa dekade terakhir ini, dilatar belakangi oleh semakin meningkatnya kasus KDRT di dunia dan buruknya efek yang ditimbulkan terhadap perempuan dan anak-anak. Efek yang ditimbulkan dari perilaku kekerasan dalam rumah tangga dari anggota keluarganya sendiri tentu lebih berdampak hebat karena dilakukan oleh orang terdekatnya. Sehingga juga berimbas pada aspek kehidupan lainnya bagi perempuan/istrinya dan juga anak-anak yang ada dalam rumah tangga tersebut.

Kekerasan dalam rumah tangga adalah kasus yang mendunia. Tidak hanya terjadi di sekitar kita bahkan di seluruh dunia. Topik tentang kekerasan dalam rumah tangga selalu menjadi topik menarik untuk dipecahkan bersama. Perlu dicarikan solusi supaya angka kasus kekerasan dalam rumah tangga dapat berkurang sehingga lambat laun kasus kekerasan dalam rumah tangga tidak lagi terjadi. Hal ini tentu sangat diharapkan banyak pihak mengingat kasus kekerasan dalam rumah tangga akan mendatangkan dampak buruk bagi banyak pihak.

Dampak dari kekerasan dalam rumah tangga adalah perasaan cemas, takut berinteraksi dan banyak trauma lainnya yang dihadapi oleh korban. Maka korban dari kekerasan dalam rumah tangga harus diberikan sebuah konseling yang akan akan membuatnya bisa meminimalkan perasaan yang tidak menyenangkan tersebut.

Salah satu solusi yang bisa dilakukan adalah dengan melakukan konseling bersama orang yang ahli dan biasa dikenal dengan istilah konselor. Konselor adalah seseorang yang memberikan bantuan kepada seorang klien dengan menggunakan teknik-teknik konseling. Kualitas konselor adalah semua kriteria keunggulan, termasuk pribadi, pengetahuan, wawasan, keterampilan, nilainilai yang dimilikinya dan akan memudahkannya dalam menjalankan proses layanan bimbingan dan konseling sehingga mencapai tujuan yang berhasil (efektif). Konselor mencoba memberikan bantuan yang berarti buat korban kekerasan dalam rumah tangga untuk meminimalkan perasaan yang tidak menyenangkan dari peristiwa kekerasan dalam rumah tangga yang pernah ia alami.

Tidak semua korban kekerasan dalam rumah tangga yang bisa cepat melupakan peristiwa yang ia alami apalagi dilakukan oleh keluarganya sendiri. Maka dari itu Pengabdian masyarakat dengan meakukan pendampingan dan penyuluhan bagi korban kekerasan rumah tangga melalui konseling dengan pendekatan behavioral sebagai salah satu meminimalkan perasaan trauma yang dimiliki korban.

\section{Methods}

Artikel ini merupakan hasil pengabdian masyarakat berbasis riset dengan melakukan riset awal terlebih dahulu untuk menggali permasalahan yang terjadi dalam rumah tangga khususnya 
Kekerasan Dalam Rumah Tangga (KDRT). Setelah permasalahan terungkap maka dilakukan pendampingan konseling bagi korban kekerasan dalam rumah tangga. Metode yang digunakan adalah penyuluhan dan pendampingan dengan mengungkap masalah, melakukan penyuluhan dan pendampingan. Kegiatan ini dilakukan berulang-ulang agar diperoleh masalah yang paling urgen untuk diselesaikan. Dalam pengabdian masyarakat ini lebih dikhusukan kepada bagaimana pendampingan konseling keluarga dengan teknik behavioral yang dilakukan dapat memberikan bantuan bagi korban kekerasan dalam rumah tangga. Korban kekerasan dalam rumah tangga yang merasa trauma dan susah dalam mengembalikan kepercayaan dirinya, diberikan bantuan konseling dengan pendekatan behavioral.

\section{Results}

\section{Pendampingan Bagi Korban Kekerasan Dalam Rumah Tangga}

Kegiatan Pendampingan dan penyuluhan masyarakat bagi orban kekerasan rumah tangga (KDRT) menjadi salah satu fokus dalam kegiatan pengabdian masyarakat yang dilakukan. Kegiatan pengabdian masyarakat ini penting untuk dilakukan oleh akademisi bagi korban kekerasan rumah tangga (KDRT), mengingat kekerasan dalam rumah tangga adalah hal yang tidak menyenangkan dan tidak diinginkan terjadi dalam diri pasangan dalam sebuah keluarga. Adanya istilah kekerasan dalam rumah tangga lebih banyak diartikan oleh kalangan masayarakat kita dari suami ke istrinya. Kekerasan dalam rumah tangga kebih bersifat suatu perbuatan tidak menyenangkan yang diberikan oleh seorang suami kepada istrinya. Suami berperilaku kasar baik secara verbal dan non verbal kepada istrinya sehingga meninggalkan trauma pada diri istri.

Kegiatan pendampingan bagi korban kekerasan dalam rumah tangga (KDRT) dilakukan bagi korban kekerasan yang umumnya disebabkan bias gender ini disebut genderrelated violence. Dalam kegiatan pengabdian berbasis riset ini terungkap bahwa kekerasan ini terjadi pada seorang lelaki yaitu suami kepada wanita yang menjadi istrinya. Pada dasarnya kekerasan gender disebabkan oleh ketidak setaraan kekuatan yang ada dalam masyarakat. Istri tidak memiliki kekuatan untuk melawan kekerasan yang dilakukan suami kepada dirinya, kalaupun membuat perlawanan hal ini tidak akan membuat kekerasan tidak berulang di kemudian harinya karena kekerasan dalam rumah tangga akan cenderung berulang dilakukan oleh suami kepada istrinya. Maka dari sesuai dengan pengungkapan dari korban KDRT tersebut maka pendampingan sekaligus penyuluhan yang dilakukan lebih difokuskan membantu keluarga yang bermasalah tersebut dengan pendekatan konseling behavior,

Penyuluhan juga dilakukan dalam kegiatan pengabdian masyarakat ini bagi para suami yang melakukan kekerasan dalam rumah tangga (KDRT), dengan memberikan pemahaman kepada para pelaku kekerasan. Para pelaku kekerasan diberikan pemahaman bahwa kekerasan yang mereka 
lakukan merupakan perbuatan yang tidak dibenar oleh agama agama maupun hukum negara. Pelaku kekerasan dalam rumah tangga harus bisa mempertanggungjawabkan perbuatannya dan akan menerima sangsi sosial dari lingkungannya. Kekerasan dalam rumah tangga bisa terjadi karena suami merasa bahwa ia memiliki otoritas tinggi terhadap istrinya, dan ia merasa bahwa istri adalah makhluk yang lemah dan bisa diperlakukan dengan semena-mena. Kekerasan terdiri atas tindakan memaksakan kekuatan fisik dan kekuasaan kepada pihak lain. Dalam kekerasan ini suami menginginkan agar ia bisa mengontrol, memperlemah dan bahkan menyakiti istrinya sendiri. Tindakan kekerasan terhadap perempuan meliputi berbagai fenomena, baik hukum, etika, kesehatan, budaya, politik, maupun moral (Zaitunah, 2004:6-7). Kekerasan dalam rumah tangga tidak dibenarkan dalam ranah hukum, dan juga tidak dianggap sebagai suatu hal yang legal secara moral. Banyak kajian ilmu yang beranggapan bahwa kekerasan dalam rumah tangga adalah sikap yang tidak baik.

Dalam tulisan Haiyun Nisa menyatakan ada beberapa bentuk kekerasan dalam rumah tangga. Menurut pasal 5 UU PKDRT No. 23 Tahun 2004, dinyatakan bahwa bentuk-bentuk KDRT adalah sebagai berikut :

a. Kekerasan fisik, yaitu perbuatan yang tidak menyenangkan pada pihak lain dan dalam hal ini ialah kepada istrinya. Perbuatan ini berdampak secara fisik kepada istri. Membuat istri terjatuh, menyebabkan istri terluka, dan bahkan ada yang menyebabkan sampai cacat tubuh dan sebainya. Dalam kasus kekerasan fisik bisa disembuhkan namun ada yang malah cacat secara permanen.

b. Kekerasan psikis, yaitu perbuatan tidak menyenangkan dan berdampak pada psikis istri. Perbuatan ini menyebabkan istri ketakutan, istri tidak percaya diri untuk berinteraksi dengan lingkungan sekitar, istri ragu dalam bertindak karena suami bisa saja memperlakukannya dengan kasar apabila tidak sesuai dengan keinginan suami. Tidak berani dalam mengambil keputusan karena merasa terancam oleh suami. Tidak berdaya sebagai seorang wanita di rumah tangga tersebut dan beberapa tekanan psikis lainnya merupakan dampak dari kekerasan dalam rumah tangga secara psikis. Tekanan psikis akan berujung pada trauma dan putus asa dalam menjalani kehidupan rumah tangganya. Bahkan beberapa orang memutuskan untuk tidak menikah karena menjadi korban dari kekerasan psikis dalam rumah tangga atau keluarga.

c. Kekerasan seksual, yaitu pemaksaan hubungan seksual yang dilakukan terhadap orang dalam lingkup rumah tangga tersebut. Kekerasan seksual bisa saja meliputi pencabulan atau perkosaan (Siregar, dkk, 2020). Contoh tindakan kekerasan seksual sendiri banyak macamnya, seperti perdagangan perempuan untuk tujuan seksual, perkosaan, pelecehan seksual dan sebagainya (Hilmi, 2019)

d. Penelantaran rumah tangga, yaitu perbuatan yang mengakibatkan ketergantuangan ekonomi dengan cara membatasi dan/atau melarang orang bekerja yang layak di dalam atau di luar rumah sehingga korban berada di bawah kendali orang tersebut. Ini sering terjadi ketika suami membiarkan istri dan anak-anak dan tidak menfkahi keluarganya. Atau suami pergi begitu saja dan meninggalkan keluarganya.

Dalam kegiatan pengabdian masyarakat ini dapat juga dipahami dan dicarikan solusi bagi korban kekerasan dalam rumah tangga (KDRT). Kekerasan dalam rumah tangga tidak hanya 
berkaitan dengan kekerasan fisik saja, tapi kekerasan secara psikis yang menyebabkan istri merasa takut kepada suaminya sendiri, atau istri merasa bahwa ia adalah orang yang tidak bisa melakukan perlawanan atau perilaku kasar dari suaminya. Bisa jadi dia mempertimbangkan anak-anak di dalam keluarga. Istri menjadi korban dari kekerasan dalam rumah tangga dari suami dan ia akan membentuk kebiasaan dari perlakuan suaminya terhadap dirinya selama ini. Perlakuan kasar yang ia dapati dan berulan-ulang akan membuat istri terbiasa disalahkan, terintimidasi dan merasa tidak percaya diri dalam mengambil sebuah keputusan

Pendampingan berupa konseling yang dilakukan bagi korban KDRT merupakan hal yang tidak asing lagi bagi banyak kalangan. Namun yang dipahami oleh banyak kalangan konseling hanya berlaku di sekolah-sekolah dan untuk siswa yang bermasalah. Anggapan itu sebenarnya salah. Karena konseling bisa diberikan kepada siapa saja dan dimana saja. Konseling diberikan oleh orang yang ahli dan diistilahkan dengan konselor kepada orang yang membutuhkan dan diistilahkan dengan klien. Konselor dan klien akan membahas masalah yang dihadapi oleh klien untuk dipecahkan bersama.

Dalam prosesnya, konseling memiliki pendekatan dan teknik yang berbeda-beda tergantung dengan masalah yang dihadapi oleh kliennya. Salah satu pendekatan dalam konseling adalah pendekatan behavioral. Konseling behavioral didasari pada hasil eksperimen yang melakukan investigasi tentang prinsip-prinsip tingkah laku manusia. Dari hasil eksperimen tersebut didapatkan hasil yang lebih khusus dan menyatakan bahwa manusia dapat diatur dan diubah sesuai dengan keinginan dari lingkungan. Hasil eksperimen awal yang dilakukan dijadikan basis dalam pengabdian masyarakat ini berupa pendampingan bagi korban kekerasan dalam rumah tangga (KDRT).

\section{Discussion}

Behavioristik berpendapat bahwa perilaku dapat dijelaskan melalui hal-hal yang dapat diobservasi, bukan melaui proses mental yang tidak dapat dilihat oleh kasat mata. Jhon Watson dan kaum behavioristik berpendapat bahwa manusia sepenuhnya adalah makhluk relatif yang tingkah lakunya dikontrol oleh faktor dari luar (Luddin, 2010:101). Ditambahkan lagi bahwa Menurut Pavlov dan Watson dikutip dari Taufik, Behavioristik mementingkan adanya pengaruh dari lingkungan sebagai bagian dari reaksi dan membentuk sebuah kebiasaan karena adanya mekanisme terbentuknya hasil dari proses belajar dan memecahkan suatu masalah (Taufik, 2009: 24). B.F. Skinner sebagai salah satu tokoh behavioristik menyatakan bahwa konseling behavioristik berfokus pada tlngkah laku yang tampak dan terlihat dan faktor luar yang menstimulasi tingkah laku tersebut muncul. Menurut Skinner, perlua adanya penekanan terhadap kontrol tingkah laku yang dimunculkan tersebut (Hidayat, 2011: 126).

Sumbangan pemikiran terbesar dari konseling behavioral adalah bagaimana memodifikasi tingkah laku yang tampak tersebut dengan sebuah rekayasa lingkungan. Dalam konseling behavioral 
konselor memandang bahwa adanya tingkah laku yang tidak normal karena kebiasaan yang dipelajari dari lingkungan. Makanya tingkah laku yang dipelajari dari lingkungan bisa diubah dengan mengganti situasi positif yang membuatnya menampilkan tingkah laku baru yang juga positif dan baik. Dan pada akhirnya perilaku yang tertekan dan gangguann psikis lainnya dapat ditekan dan berubah menjadi perilaku yang menyenangkan (Muslih, dkk, 2017). Pendekatan konseling behavioral beranggapan bahwa korban dari kekerasan dalam rumah tangga memiliki perilaku yang tidak biasa seperti gangguan psikis disebabkan pengaruh dari lingkungan. Suami yang mengintimidasi istri dan memberikan perlakuan kasar pada istri adalah suatu lingkungan buruk bagi istri. Istri mempelajari bahwa apabila ia berbuat sesuatu dan salah menurut suaminya maka ia akan diberikan sebuah tindakan kekerasan baik secara fisik maupun psikis.

Adapun mengenai faktor yang menyebabkan terjadinya kekerasan dalam rumah tangga adalah dari faktor internal dan faktor eksternal. Faktor-faktor yang menyebabkan terjadinya kekerasan dalam rumah tangga yaitu perselingkuhan, masalah ekonomi, campur tangan pihak ketiga, bermain judi, budaya patriarkhi, serta perbedaan prinsip (Jayanthi, 2009). Jadi untuk terjadinya perilaku maladaptive kekerasan dalam rumah tangga tersebut bisa disebabkan oleh satu atau dua faktor yang telah disebutkan di atas. Kalah dalam bermain judi menyebabkan suami stres dan akhirnya melampiaskan kekesalannya kepada istrinya dirumah. Menganggap bahwa istri tidak memahami kondisinya yang sudah kalah dalam permainan dan setiba di rumah istri minta uang untuk belanja bulanan. Atau faktor perselingkuhan juga menyebabkan kekerasan dalam rumah tangga. Suami yang sudah tidak memiliki rasa kasih sayang lagi kepada istri dan melihat adanya pesona yang lebih menawan dari wanita di luar pernikahannya. Suami mencoba mencari alasan supaya dapat berpisah dengan istrinya. Jadi perilaku kekerasan dalam rumah tangga akan terjadi karena faktor-faktor ini. Perilaku maladaptive tidak akan terjadi tanpa adanya faktor yang melatarbelakanginya.

Sejalan dengan pendapat sebelumnya, Sigit menyatakan dalam konsep behavior, perilaku manusia bisa diubah dengan mengkreasikan keadaan lingkungan sekitar dan memanipulasi kondisikondisi yang memungkinkan korban/klien membentuk sebuah tingkah laku yang baru. Proses konseling merupakan suatu proses atau pengalaman belajar untuk membentuk klien membentuk tingkah laku baru yang lebih positif dan pada akhirnya masalah bisa terpecahkan (Sanyata, 2012). Konselor akan memberikan modifikasi tingkah laku dan klien akan belajar bahwa perilaku selama ini adalah salah dan ia bisa mengubah tingkah lakunya menjadi tingkah laku baru yang ia pelajari dari konselor. Pandangan behavioristik mengakui pentingnya sebuah stimulus yang pada akhirnya akan menghasilkan sebuah output dalam bentuk respons. Teori belajar behavioristik menekankan pembahasan kajiannya adalah pada pembentukan sebuah tingkah laku yang didasarkan pada hubungan stimulus respon dan hal ini bisa diamati dan tidak dihubungkan pada kesadaran seseorang (Sakinah, 2018). 
Dalam menerapkan pendekatan konseling behavioristik dalam kegiatan pengabdian masyarakat ini, pengabdi sekaligus konselor memberikan sebuah stimulus yang akan mengeluarkan sebuah respon dan diharapkan lingkungan. Pada dasarnya tingkah laku bisa diprediksi dan bisa diramal apa yang akan dilakukan klien apabila ia diberikan sebuah stimulus tertentu.

Tujuan pendampingan konseling dalam pendekatan behavioristik berorientasi pada pengubahan atau modifikasi perilaku klien yang yang dilakukan dalam pengabdian masyarakat ini diantaranya adalah sebagai berikut:

- Menciptakan kondisi baru sehingga dalam hal ini klien memperoleh sebuah proses belajar yang baru. Klien yang menjadi korban kekerasan dalam rumah tangga diharapkan dapat memeproleh sebuah pembelajaran karena dengan penciptaan suatu kondisi baru klien akan dipengaruhi oleh lingkungannya yang baru. klien yang terbiasa tersudutkan maka diganti dengan kondisi dimana ia menjadi seorang yang diprioritaskan.

- Penghapusan hasil belajar yang tidak adaptif. Klien hendaknya diajak untuk menghapus tingkah laku-tingkah laku yang tidak bisa sesuai dengan tuntutan lingkungan. Dengan tingkah laku yang tidak adaptif tersebut akan membuat klien tidak bisa bersosialisasi dengan orang disekitarnya atau malah menarik diri dari situasi yang memnintanya untuk bersosialisasi.

- Memberi pengalaman belajar yang adaptif namun belum dipelajari. Klien diberikan sebuah pengalaman baru yang diterima oleh lingkungan dan hal ini belum pernah ia temui sebelumnya. Klien yang menjadi korban kekerasan dalam rumah tangga yang awalnya diberikan sebuah perlakuan yang sebelumnya belum pernah ia dapatkan.

- Membantu klien membuang tingkah laku yang maladaptif dan menggunakan respon baru yang lebih tepat dan adaptif. Awalnya klien malu untuk berpendapat, maka setelah proses konseling diharapkan klien mau berpendapat dan bebas mengungkapkan apa yang ia rasakan.

- Diharapkan nantinya klien belajar tingkah laku baru dan mengeliminiasi tingkah laku yang tidak sehat, serta mempertahankan tingkah laku yang diinginkan. Sehingga ketika klien kembali dihadapkan pada masalah yang sama klien tidak lagi mengeluarkan tingkah laku tertekan, pasrah dan tidak bisa berinteraksi dengan sosialnya.

- Penetapan tujuan dan tingkah laku serta upaya pencapaian sasaran dilakukan bersama konselor dan klien. Klien yang berada pada keadaan tidak stabil, tentu akan kesulitan dalam merumuskan tujuan konseling. Maka ia akan dibantu oleh konselor dalam 
merumuskan apa saja tujuan yang bisa dituju dan dicapai setelah pelaksanaan konseling tersebut.

Dalam proses konseling, konselor membentuk suatu suasana yang memang baru bagi klien. Perilaku maladaptive yaitu kekerasan dalam rumah tangga diubah menjadi perilaku adaptive yaitu perilaku lemah lembut. Klien dengan sendirinya bisa mengidentifikasi mana perilaku baik yang harus ia pertahankan dan mana perilaku buruk yang harus ia tinggalkan. Klien bersama dengan konselor merumuskan apa yang ingin dicapai setelah proses konseling dengan pendekatan behavioristik ini.

Jadi Pendampingan konseling behavioral bagi korban kekerasan rumah tangga lebih menekankan pada perilaku yang dimiliki oleh inidividu. Yang menjadi sasaran dalam konseling behavioral apabila perilaku tersebut tidak bisa diterima lingkungan maka lingkungan yang akan membetuk tingkah laku baru untuk individu tersebut.

Teknik yang dipakai dalam masalah klien yang menjadi korban kekerasan dalam rumah tangga, dalam kegiatan pendampingan bagi korban kekerasan dalam rumah tangga dalam kegiatan pengabdian masyarakat ini adalah:

\section{a. Teknik Percontohan (Modelling)}

Teknik modeling adalah suatu teknik yang ada dalam konseling dan meminta klien untuk mencontoh dari model yang dijadikan konselor sebagai contoh yang tepat. Teknik modelling, melatih klien untuk mencontoh perilaku orang yang ada disekitarnya. Ada kecakapan sosial yang bisa didapatkan oleh klien setelah ia diberikan teknik modeling (Gading, dkk, 2017). Melalui teknik modeling maka klien dapat meningkatkan tingkah laku prososialnya (Usman, 2017). Teknik modeling lebih mengarah kepada pembentukan tingkah laku klien agar bisa melakukan interaksi dengan orang di sekitarnya dan tingkah laku tersebut sesuai dengan harapan orang sekitarnya.

Melalui teknik modeling, klien belajar melalui observasi dengan menambahkan atau mengurangi tingkah laku yang sekarang ia miliki. Selanjutnya dari tingkah laku yang ia amati tersebut ia akan menggenaralisasi berbagai pengamatannya dan ia juga akan memanfaatkan kognitifnya untuk berfikir mengenai tingkah laku yang akan ia contoh tersebut (Damayanti, 2016). Selama diberikan teknik modeling diharapkan klien memang menggunakan seluruh perhatiannya untuk melihat tingkah laku apa yang akan ia ubah dan memikirkan dari tingkah laku model tersebut mana yang perlu ia terapkan dalam kehidupannya sehari-hari.

Klien mengamati seorang model dan kemudian diperkuat untuk mencontoh tingkah laku sang model. Belajar yang bisa diperoleh melalui pengalaman secara langsung bisa pula 
diperoleh secara tidak langsung dengan mengamati tingkah laku orang lain berikut konsekuensi-konsekuensinya (Corey, 2005:222). Jadi klien diperlihatkan sebuah video atau tayangan yang menampilkan korban kekerasan dalam rumah tangga lainnya. Korban kekerasan dalam rumah tangga tersebut mencoba bangkit dari tekanan psikis dan berhasil keluar dari keterpurukannya. Bagaimana ia bisa membesarkan anak dan menjadikan anakanaknya sukses.

Dari percontohan ini diharapkan klien mempelajari kecakapan-kecakapan sosial yang layak untuk ditiru. Hendaknya juga klien terpancing untuk mempertahankan rasa cinta dan kasih sayang yang ada dalam dirinya untuk anaknya sehingga berusaha berjuang demi keluarganya.

Perlu diketahui bahwa teknik modelling ini konselor harus benar-benar memfilter tayangan yang tepat untuk kliennya. Karena kesalahan dalam pemilihan modelling tidak akan memberikan efek apapun kepada klien tersebut. Modelling harus lah yang benar-benar memiliki image bagus di mata klien atau benar-benar layak untuk menjadi panutan untuk klien.

\section{b. Pemberian reward/punishment secara selektif}

Konselor meneliti klien dalam situasi yang alamiah, bekerjasama dengan anggota keluarga lainnya untuk memberikan reward ketika klien melakukan tingkah laku yang diinginkan. Dan memberikan hukuman/punishment ketika ia melakukan tingkah laku yang tidak dihendaki.

Terjadinya perilaku kekerasan dalam rumah tangga sebelumnya terjadi di dalam sebuah hubungan pernikahan salah satu penyebabnya adalah pelaku tidak diberikan punishment atas tingkah lakunya. Sehingga tingkah laku tersebut ia ulangi lagi dia lakukan lagi. Tidak adanya perlawanan dari korban dan tidak adanya teguran dari anggota keluarga lainnya menyebabkan perilaku ini terus berulang. Maka didalam pelaksanaan konseling behavioral ketika tingkah laku tersebut dilakukan oleh pelaku maka berikan sebuah punishment. Punishment disini bisa bekerja sama dengan pihak berwajib atau polisi. Pelaku kekerasan dalam rumah tangga berlaku maladaptive maka minta polisi untuk memberikan pelajaran kepada pelaku. Ketika pelaku sudah tenang kembali maka biarkan ia berinteraksi lagi dengan korban. Muncul lagi maladaptive, maka beri punishment lagi. Korban yang diberikan perlindungan seperti ini akan merasa dihargai, dan ia akan merasa bahwa ia tidak sendiri dalam menghadapi suaminya yang menjadi pelaku kekerasan dalam rumah tangga. 
Karena ini adalah dalam suatu sistem keluarga, maka yang akan memberikan reward dan punishment adalah dari anggota keluarga lainnya juga kepada pelaku kekerasan dalam rumah tangga. Sementara korban kekerasan dalam rumah tangga jangan diintimidasi dan disampaikan bahwa ia memiliki kekurangan sehingga suami tidak menyanyangi dan mencintai dirinya.

Untuk klien sendiri, selama proses konseling klien harus diberikan reward yang tepat ketika klien menunjukkan tingkah laku yang tidak lagi dalam keadaan tertekan dan tidak lagi ketakutan. Konselor mendorong perubahan tingkah laku klien agar ia lebih adaptif dan tidak lagi menjadi orang yang terisolasi dari lingkungannya. Ketika perubahan terjadi reward adalah teknik yang tepat untuk klien tersebut.

Namun yang perlu diteliti oleh konselor adalah, ia harus menemukan reward dan punishment yang tepat untuk kliennya. Apakah tepat ia bekerja sama dengan pihak kepolisian untuk memberikan hukuman kepada pelaku kekerasan dalam rumah tangga dan menciptakan reward kepada korban. Atau klien pada hakikatnya tidak meninginkan suaminya ditindak oleh pihak berwajib, ini harus dipertimbangkan terlebih dahulu oleh konselor. Hal ini yang harus ditetapkan oleh konselor dengan mempelajari karakter dari kliennya. Pemilihan reward dan punishment yang tepat akan membuat konseling behavioral ini efektif.

Konselor harus mengetahui kekuatan dari lingkungan yang dapat memperngaruhi tingkah laku klien. Klien yang merasa bahwa ia perlu dukungan dari keluarga suaminya maka konselor harus mengikutsertakan keluarga suami untuk memberikan support bukan malah menyudutkan klien. Karena konsep dari konseling keluarga adalah sistem yang tidak boleh dipisahkan satu dengan yang lainnya.

\section{c. Rileksasi}

Rileksasi adalah teknik dalam konseling behavioral yang meminta pada klien untuk berada dalam keadaan tenang dan dalam suasana emosi yang stabil. Rileksasi digunakan untuk meredakan emosi yang menggelora dan sulit dikendalikan oleh individu tersebut. Dalam kasus klien yang menjadi korban dari kekerasan dalam rumah tangga, maka diharapkan klien bisa mengendalikan perasaan tertekan yang ia miliki. Rasa frustasi dan merasa tidak berdaya dan tidak berharga akan ia kendalikan melalui teknik rileksasi

Latihan rileksasi ini dianggap berhasil menyembuhkan klien yang menderita susah tidur, sakit kepala dan beberapa sakit fisik yang ditimbulkan dari perasaan tertekan dari perilaku kekerasan dalam rumah tangga ntersebut. 


\section{d. Penguasaan Diri (SelfControl)}

Dengan teknik self control, klien yang menjadi korban kekerasan dalam rumah tangga dimungkinkan untuk memiliki acuan untuk mengahdapi masalahnya tersebut. Adapun dasar dari teknik ini adalah:

- Apabila klien diberikan peran aktif dalam menyelesaikan masalahnya, maka ia akan lebih mudah dalam mencapai tujuannya. Karena ia berusaha untuk memberikan yang terbaik selama proses konseling. Konselor pun akan menjadi semangat juga untuk membantu penyelesaian masalah klien.

- Klien dapat memperoleh keterampilan dalam mengurus diri untuk menghadapi masalah. Klien akan mencoba menemukan keterampilan apa yang ia bisa gunakan dalam penyelesaian masalah. Canggung dalam berkomunikasi maka dalam teknik mengontrol diri ia akan berusaha mengontorl diri supaya tidak menjauh dari keramaian dan mencoba untuk melebur dalam kelompok tersebut.

- Perubahan akan menetap apabila klien sendiri yang menginginkan perubahan tersebut. Dan dalam perubahan ini akan membuat perilaku tersebut menetap dalam diri klien. Ketika ia menghadapi masalah ia tidak langsung jatuh pada kondisi tertekan. Namun ia akan mencoba sebisa mungkin untuk mengontrol diri supaya tidak terjerumus dalam suatu masalah.

Maka dengan teknik yang sudah disebutkan di atas, seorang konselor bisa membantu korban dari perilaku kekerasan dalam rumah tangga yang tiap tahun semakin bertambah. Teknik haruslah dipertimbangkan kapan baiknya teknik ini diterapkan dan kapan teknik lainnya mendukung pelaksanaan teknik yang lain.

Teknik konseling behavioral dapat efektif apabila klien sendiri juga mengusahakan terjadinya perubahan dalam tingkah lakunya. Klien yang aktif dalam proses konseling lah yang diinginkan dalam proses ini. Konseling behavioral diharapkam memberikan kontribusi yang cukup siginifikan dalam perubahan tingkah laku klien yang menjadi korban dalam kekerasan dalam rumah tangga.

\section{Conculations}

Pengabdian masyarakat ini yang dilakukan ini berupa pendampingan konseling bagi pelaku kekerasan dalam rumah tangga agar sikap yang tidak dibolehkan dan tidak layak dilakukan oleh pasangan suami istri dalam rumah tangga, karena melanggar banyak norma dan nilai yang berlaku di tengah masyarakat. Walaupun suami sudah memiliki wewenang atas istrinya setelah adanya 
pernikahan, namun hendaknya kekerasan tetap tidak dapat dibenarkan atas alasan apapun itu. Konseling behavioral yang dilakukan dalam pengabdian masyarakat ini, melakukan pendampingan untuk menangani klien-klien yang menjadi korban perilaku kekerasan dalam rumah tangga. Konselor sebagai pendamping dalam pengabdian masyarakat ini berupaya sebaik mungkin untuk membantu klien mengubah tingkah lakunya ke arah yang lebih baik. Adapun tekhnik konseling behavior yang dilakukan untuk klien yang menjadi korban perilaku kekerasan dalam rumah tangga adalah teknik percontohan (modelling), dan teknik punishment/reward, rileksasi, dan self control. Masing-masing teknik harus dikombinasikan penggunannya sesuai dengan keadaan klien masing-masing.

Harapan dari kegiatan pengabdian masyarakat berupa pendampingan konseling behavior bagi korban kekerasan dalam rumah tangga, agar korban kekerasan dalam rumah tangga dapat kembali hidup normal tanpa dihantui bayang-bayang kekerasan dan juga agar dalam menjalani kehidupan berumah tangga dengan kehidupan yang harmonis sebagai tujuan dari hidup berumah tangga.

\section{Daftar Pustaka}

Abu Bakar M. Luddin. (2010). Dasar-dasar Konseling Tinjauan Teori dan Praktek. Bandung: Citapustaka Media Perintis

Annas Sholahuddin. (2010). Bimbingan Dan Konseling. Bandung: CV. Pustaka Setia

Dede Rahmat Hidayat. (2011). Psikologi Kepribadian Dalam Konseling. Jakarta: Ghalia Indonesia

Edwin Manumpahi, \& Shirley Y.V.I. Goni \& Hendrik W. Pongoh. Kajian Kekerasan Dalam Rumah Tangga Terhadap Psikologi Anak Di Desa Soakonora Kecamatan Jailolo Kabupaten Halmahera Barat. e-journal acta diurna, Vol 5 No.l. Tahun 2016

Evi Tri Jayanthi. Faktor-Faktor Penyebab Terjadinya Kekerasan Dalam Rumah Tangga Pada Survivor Yang Ditangani Oleh Lembaga Sahabat Perempuan Magelang. Jurnal DIMENSIA, Volume 3, No. 2, September 2009

Gantina Komala Sari, Eka Wahyuni dan Karsih. (2011). Teori dan Teknik Konseling. Jakarta: PT. Indeks

Gerald Corey. (2005). Teori dan Praktek Konseling dan Psikoterapi. Bandung: PT. Refika Aditama

Haiyun Nisa. Gambaran Bentuk Kekerasan Dalam Rumah Tangga Yang Dialami Perempuan Penyintas. Gender Equality: International Journal of Child and Gender Studies, Vol. 4, No. 2, September 2018

Hilmi, Mella Fitriyatul. Kekerasan Seksual dalam Hukum Internasional. Jurist-Diction: Vol. 2 No. 6, November 2019, p. 2199-2218

Komnas Perempuan. 2020. Catatan Kekerasan Terhadap Perempuan Tahun 2019, https://Www.Komnasperempuan.Go.Id/File/Pdf_File/2020/Catatan\%20Tahunan\%20Kekerasa n\%20Terhadap\%20Perempuan\%202020.Pdf, Akses pada tanggal 3 September 2020.

Mansour Fakih. (2012). Analisis Gender dan Transformasi Sosial. Yogyakarta: Pustaka Pelajar

Novi Hendri. (2013). Model-Model Konseling. Medan: Perdana Publishing

Sigit Sanyata. Teori dan Aplikasi Pendekatan Behavioristik dalam Konseling. Jurnal Paradigma, No. 14 Th. VII, Juli 2012

Silfia Hanani. "Mengatasi Kekerasan dalam Rumah tangga Melalui Institusi Adat Minang Kabau (Suatu upaya Dalam mewujudkan Kesejahteraan Berbasis Perspektif Lopklitas Religius)", AICIS Conference Proceeding, UIN Sunan Ampel Surabaya, 2013, 1.

Taufik. (2009). Model-Model Konseling. Padang: FIP UNP 
Ummul Sakinah. Konseling Behavioristik Dalam Membentuk Perilaku Mandiri Merawat Diri Pada Tunagrahita. Hisbah: Jurnal Bimbingan Konseling dan Dakwah Islam Vol. 15, No. 1, Juni 2018

Yuyun Nuriyah Muslih, Mungin Eddy Wibowo \& Edy Purwanto. Konseling Behavioral menggunakan

Teknik Kontrak Perilaku dengan Students' Logbook untuk Meningkatkan Minat Membaca Siswa. Jurnal Bimbingan Konseling. JUBK 6 (1) (2017)

Zaitunah Subhan. (2004). Kekerasan terhadap Perempuan. Yokyakarta: LKIS Pelangi Aksara 